\title{
Traffic Noise Influence on Soundscape Quality At Campus Landscape Area
}

\author{
Engku Mastura Engku Mohd Anuar*, Nazli Bin Che Din and Hazreena Hussein \\ Department of Architecture, Faculty of Built Environment, University of Malaya, 50603 Kuala Lumpur, \\ Malaysia \\ *engkumastura@gmail.com
}

Received: 26 October 2015 Final Version Received: $31^{\text {st }}$ March 2017

Campuses located in urban areas are prone to issues such as high traffic and noise pollution which can affect both the indoor and outdoor learning environments. Environmental experiences involving the perception of positive and negative sounds relate to the study of soundscape. This paper presents a soundscape assessment using two physical approaches of site observation and sound measurement. Two landscape areas in University of Malaya (UM) campus were selected: the parcourse area (Site I) and the water feature area (Site II). The objectives are to investigate the level of sound quality and to identify the connection between the soundscape and the landscape elements. During site observation, the human sound of Site I, water sound of Site II and vehicular sounds characterize the selected sites. Both sites sound pressure level were at $50 \mathrm{dBA}$ and above during low traffic conditions, and a critical level of over $60 \mathrm{dBA}$ during high traffic conditions. This current sound level exceeded the permissible level for institutions of $50 \mathrm{dBA}$ by the Department of Environment. Sounds generated by the water feature and from human activities do influence the soundscape during low traffic period but insignificant during high traffic period. It is important to take into consideration on the factor of location, surrounding context, landscape elements and vegetation when creating a landscape area for the community in the campus. It is hoped that the findings will provide fundamental data for future improvement and development of UM campus' landscape areas.

Keywords: Soundscape, Traffic Noise, Landscape Elements, Campus Environment.

\section{INTRODUCTION}

Densely populated urban cities are often associated with the increase in traffic that leads to noise pollution (Raimbault \& Dubois, 2005; Goswami et al., 2011). One of the major contributions to noise emanates from the transportation sector (Goswami et al., 2011). A campus can be reflected as a small city that experiences the issues of traffic and noise.
Nowadays there is a necessity of using private transportation as it eases one's mobility, especially within a large campus area. Traffic noises and quantity of car parks at a university campus indicates the ever growing use of vehicles by the campus community or outsiders is the main contribution to the excessive noise problem (Musa et al., 2012) within the campus (Kong et al., 2009; 
Barata et al., 2011). The increased use of private vehicles, the location of the campus and the traffic movement influence the high sound level that could affect human health (El-Sharkawy \& Alsubaie, 2014). Goswami et al. (2011) and Ozer et al. (2014) studied traffic noise within a campus, and the research showed that the sound level at certain locations exceeded the permissible sound level. Excessive exposure to traffic sound can accentuate the negative effect on human health. It is an environmental problem that can cause health hazard, environmental degradation, and influence the quality of life (Phukan \& Kalita, 2013; Ozer et al., 2014). The usage of vehicles affected the indoor and outdoor environment and brings about negative impact on the quality of life in a campus (Kong et al., 2009). Green spaces are provided around a campus for students to enjoy outdoor activities where they can experience an environment that would be benefitting to their health. The quality of recreation spaces that aim to promote healthy lifestyle can be improved by the existence of soothing sounds of nature. However, it can easily deteriorated by acoustic disturbances (Yang and Kang, 2005).

Sound is one of the important elements that constitute an environment, and it relates exclusively with people's sense of hearing. Environmental sound differs with time, space and location (Raimbault \& Dubois, 2005; Botteldooren et al., 2006). The environment naturally produces sounds, but over time, they are being toned down by human interventions with more distinct sound (Pijanowski et al., 2011). Sound is rarely being recognized as informative elements, but instead, they are being apprehended as noise and pollutant of the environment (Carles et al., 1999). Noise is referred to as undesired sound which implies a negative impression (Jennings \& Cain, 2013) that can decrease the value of landscape in both urban and rural areas. Raymond Murray Schafer pioneered the term and study of soundscape to create a better quality of life by viewing sound from different dimensions other than the context of noise (Schafer, 1977). The term soundscape was derived from the word sound, which is the energy wave transmitted in the form of vibration (Kang, 2007); and landscape, which is an area with visible features that can be sensed (Eckbo et al., 1998). Other terms that can be defined as soundscape are 'sonic environment' (Schafer, 1977), 'environment of sound' (Truax, 1996), 'auditory or aural landscape' (Thompson, 2002), and 'acoustic environment' (Brown et al., 2011). The environment of sound is a holistic system that looked into a multi-dimensional entity of sound, environment, and people (Ozcevik \& Can, 2012; Brown et al., 2011; Kang \& Zhang, 2010; Davies et al., 2013).

Previous and recent studies acknowledged the changes in the soundscape, with a specific focus towards urban areas such as urban public open space (Yang \& Kang, 2005; Kang \& Zhang, 2010; Yu \& Kang, 2011; Marry \& Defrance, 2013), urban residential area (Skånberg \& Öhrström, 2002; Yu \& Kang, 2011), and underground shopping streets (Meng et al., 2013). Most acoustical studies done on campuses looked into the aspects of sound, environment, and people; but directed towards noise and annoyances influencing the learning environment (Jaff \& Hossieni, 2012; Zannin et al., 2013; Ozer et al., 2014). People's 
experience of an outdoor environment relates closely with the existing sound in the area (Brown \& Muhar, 2004). The sound of environment is a combination of natural sound from birds or water; human sound from people talking or laughing; and mechanical sound from vehicles or construction, among other things (Kawai \& Yano, 2002; Yang \& Kang, 2005; Kang \& Zhang, 2010; Brown et al, 2011). This study focuses on the aspects of sound, landscape area, and people within a campus. The study would be concentrated on soundscape assessment through sound measurement and observation at two landscape areas in UM campus. The aim of this research is to assess the quality of soundscape and landscape in selected areas around UM campus. Based on this aim, the following objectives are formulated:

i. To investigate the level of sound quality at two selected landscape area.

ii. To identify the connection between the sounds and landscape elements.

\section{LITERATURE REVIEW}

Sound can be referred to various sound types and sources that can be perceived as positive or negative (Brown et al., 2011). Preferred sounds are sounds that offer positive feelings to the listener (Carles et al., 1999; Viollon et al., 2002; Yang \& Kang, 2005; Davies et al., 2013). Undesired sounds are sound that evokes negative emotions or feelings such as annoyance, which interferes with activities or damage hearing (Brown et al., 2011). Planners or decision makers concerned with noise complaints and management often looked into reducing and eliminating negative sounds, rather than trying to enhance the value of positive sound (Raimbault \& Dubois, 2005; Cain et al., 2013).
They focus on controlling the negative sound which leads urban soundscape towards the 'less unpleasant' without being more 'pleasant' (Kawai \& Yano 2002; Cain et al., 2013). Simply decreasing or eliminating negative sound can lead to anxiety and create other problems, besides being insufficient for the account of improving urban environment (Kang \& Zhang 2010; Jennings \& Cain, 2013; Cain et al., 2013).

The purpose and function of an area influence the type of sound created in it (Mastura et al., 2014). Depending on a space, sound may be described and valued differently (Brown et al., 2011). Consideration of individual sound is an important part of soundscape evaluation (Kang, 2007). Correspondence between sounds and the environmental context, which supports the activities undertaken by people, would result in quality soundscape (Kin-Che et al., 2010). Different places and context produce its own soundscape that is unique from one another (Brown et al., 2011). The context of the soundscape is an important yet challenging aspect that needs to be considered in the study of soundscape (Cain et al., 2013). It is due to sounds coming from different sources from within the area, and from the outside of the area. The site context relates behavior and activity whether or not it is compatible and meets the expectation of the users (Davies et al., 2013). The context of an area, including auditory information, is rarely perceived in isolation from other sensory such as the sense of vision and touch (Viollon et al., 2002). People's preferences for a particular landscape are determined by both the emotional attributes of sound, and the contextual elements it is perceived in (Carles et al., 1999). 
Different components of the environment can be enhanced and emphasize through information provided by sounds that are beyond the context alone.

\section{METHODOLOGY}

Research on soundscape in urban areas is typically conducted at places such as public open spaces, where engagement between human and sounds existed (Yang \& Kang, 2005; Kang \& Zhang, 2010; Yu \& Kang, 2011; Marry \& Defrance, 2013). This research focuses on landscape areas within UM campus. The selected areas are the parcourse area (Site I) and the water feature area (Site II). The areas were selected based on the presence of landscape elements which are capable of contributing to either natural or human sound. Site I which contains parcourse equipment attract human interactions through physical activities which in turn create human sounds. Site II which comprises of water element generated the effect of waterfall sound when it is in operation. They are both located along the main road, which is accessible through Kuala Lumpur (KL) and Petaling Jaya (PJ) entrance gates, with high possibility of being influenced by traffic noise (Figure 1). Criteria for the selection of the sites were based on the provision of outdoor environment, availability of landscape element and its sound source, as well as its location and accessibility.

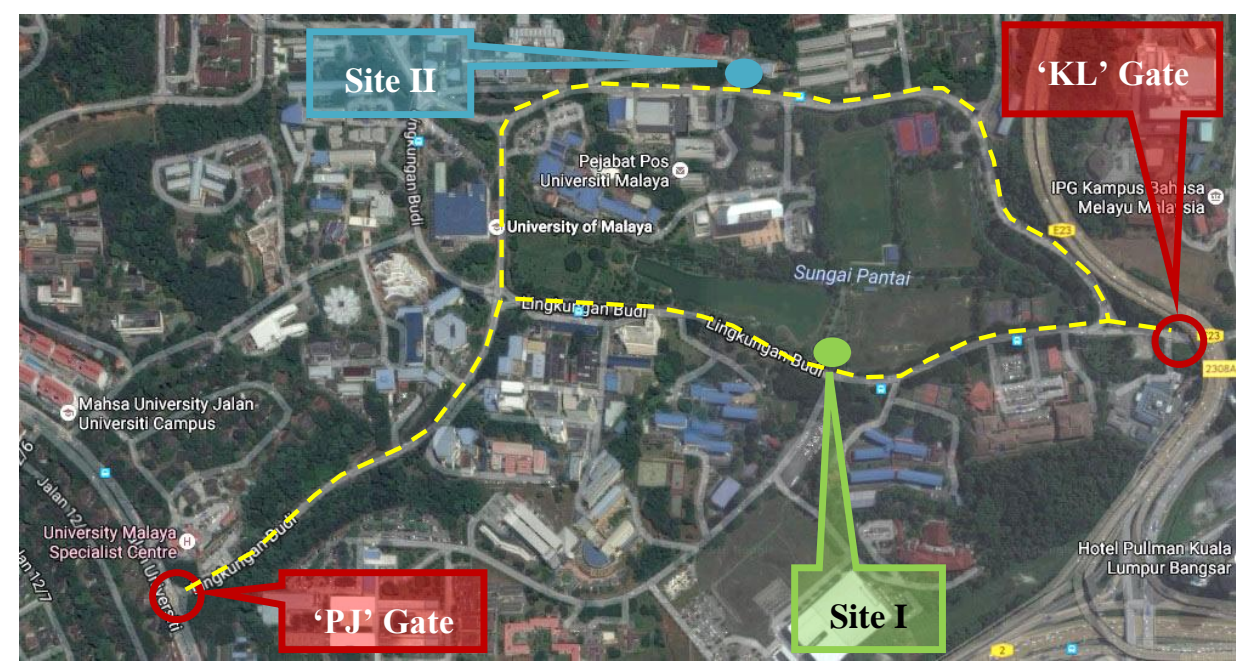

Figure 1: Satellite view of UM campus. (Source: Google Earth)

\subsection{DATA COLLECTION}

Research by Yang and Kang (2005), Kang and Zhang (2010), and Meng et al. (2013) include the assessment of sound pressure level (SPL) and sound environment questionnaire survey as part of their studies. In this study, physical assessment through site observation and sound measurement aims to identify and understand the current sound condition of the site. The measurement works were carried out according to the standard outlined in Planning Guidelines for Environmental Noise Limit and Control by the Department of Environment (D.o.E, 2007). The measurement of SPL was done using sound level meter $01 \mathrm{~dB}$ SOLO Metravib. The measured SPL parameters 
are A-weighted sound pressure level $\left(\mathrm{L}_{\mathrm{Aeq}}\right)$, minimum A-weighted sound pressure level $\left(\mathrm{L}_{\mathrm{Amin}}\right)$ and maximum A-weighted sound pressure level $\left(\mathrm{L}_{\text {Amax }}\right)$. Following the standard drawn in Planning Guidelines for Environmental Noise Limits and Control 2007, the sound level meter was mounted on a tripod stand at a height of 1.2 to 1.5 meter above ground and at least 3.5 meters away from any walls, buildings, and other sound reflecting structures. The half inch microphone on the sound level meter was also secured with a wind protector. It is then located at one point of reference in each site during the measurement. The selected point of reference represents the main spot where people perceived sound at that particular landscape area (refer Figure 3 and Figure 6).

The data collection was conducted in the month of October and November in 2013. The sound level meter was set to run the measurements for two hours duration. The equipment was checked every half an hour to make sure that the measurement is recorded throughout the duration of the measurement. To ensure the safety of the equipment, a notice regarding the research purpose was placed on it to avoid any disturbances from the passerby, while still being monitored from a distance of about 10 to 20 meters. Observation on the site context and landscape elements was done one month earlier for identification purposes before conducting the sound measurement. A digital camera was used to capture the visual of the selected landscape areas. The layout plan of the sites was sketched to indicate the site context and landscape elements. Observation on the sound elements, human activity, and number of passing by vehicles was done during the sound measurement. The vehicle types are divided into four categories: car, motorcycle, lorry, and bus.

The time and day of the measurement were selected in order to achieve the preferred site conditions (Table 1). The different days selection were done to achieve the high and low traffic circumstances. The measurements for high traffic condition were conducted during the weekdays, while the measurements for low traffic conditions were conducted during holiday, weekend and weekday. The differences in timing schedule for all the measurement periods are due to the factor of human presence, as well as the operational time of the water feature.

Table 1: Schedule of measurements in Site I and Site II.

\begin{tabular}{|c|c|c|c|c|}
\hline \multicolumn{5}{|c|}{ a) Site I } \\
\hline \multirow{3}{*}{ Legend } & High Traffic- & High Traffic- & Low Traffic- & Low Traffic- \\
& Human & No Human & Human & No Human \\
& Presence & Presence & Presence & Presence \\
\cline { 2 - 5 } & $\mathrm{I}_{\mathrm{H}, \mathrm{w} \_\mathrm{H}}$ & $\mathrm{I}_{\mathrm{H}, \mathrm{w} / \mathrm{o} \_\mathrm{H}}$ & $\mathrm{I}_{\mathrm{L}, \mathrm{w} \_\mathrm{H}}$ & $\mathrm{I}_{\mathrm{L}, \mathrm{w} / \mathrm{o} \_\mathrm{H}}$ \\
\hline \multirow{3}{*}{ Day } & Weekday & Weekday & Holiday & Weekend \\
& (Thursday) & (Monday) & (Raya Haji) & (Sunday) \\
\hline \multirow{2}{*}{ Time } & $1700-1900$ & $0850-1050$ & 0925-1125 & 1350-1550 \\
\hline \multicolumn{7}{|c}{} & b) Site II \\
\hline
\end{tabular}




\begin{tabular}{|c|c|c|c|c|}
\hline \multirow{2}{*}{ Legend } & $\begin{array}{c}\text { High Traffic- } \\
\text { Water Feature } \\
\text { (on) }\end{array}$ & $\begin{array}{c}\text { High Traffic- } \\
\text { Water Feature } \\
\text { (off) }\end{array}$ & $\begin{array}{c}\text { Low Traffic- } \\
\text { Water Feature } \\
\text { (on) }\end{array}$ & $\begin{array}{c}\text { Low Traffic- } \\
\text { Water Feature } \\
\text { (off) }\end{array}$ \\
\cline { 2 - 5 } & $\mathrm{II}_{\mathrm{H}, \mathrm{w} \_\mathrm{ON}}$ & $\mathrm{II}_{\mathrm{H}, \mathrm{w} /{ }_{0} \mathrm{O} F \mathrm{FF}}$ & $\mathrm{II}_{\mathrm{L}, \mathrm{w} \_\mathrm{ON}}$ & $\mathrm{II}_{\mathrm{L}, \mathrm{w} /{ }_{0} \mathrm{O} \text { OFF }}$ \\
\hline \multirow{2}{*}{ Day } & $\begin{array}{c}\text { Weekday } \\
\text { (Tuesday) }\end{array}$ & $\begin{array}{c}\text { Weekday } \\
\text { (Friday) }\end{array}$ & $\begin{array}{c}\text { Holiday } \\
\text { (Raya Haji) }\end{array}$ & $\begin{array}{c}\text { *Weekday } \\
\text { (Monday) }\end{array}$ \\
\hline Time & $0700-0900$ & $0915-1115$ & $0700-0900$ & $0700-0900$ \\
\hline
\end{tabular}

*Weekday (Monday): in between weekend and public holiday (Raya Haji)

\section{RESULTS}

The results and discussions are based on both site observation and sound measurement. Analysis for each Site I and Site II are divided into three sections: site observation, sound measurement, and discussion.

\subsection{SITE I (PARCOURSE AREA)}

\subsubsection{SITE OBSERVATION}

Site I provided parcourse equipment for the campus community members to enjoy either active or passive activities such as exercising and socializing. It was observed that the site is usually crowded in the evenings. There is a gazebo nearby used as a place for waiting, sitting, and sight viewing. The site is located next to an open green space and lake area. It is surrounded by primary, secondary, and tertiary road. There are pines and trees planted along the primary road that is still immature in terms of heights and sizes. Therefore, the site is visually and audibly exposed to the sound of passing vehicles. Figure 2 shows the images of Site I and its context, and Figure 3 presents the layout plan and panoramic images of the site.

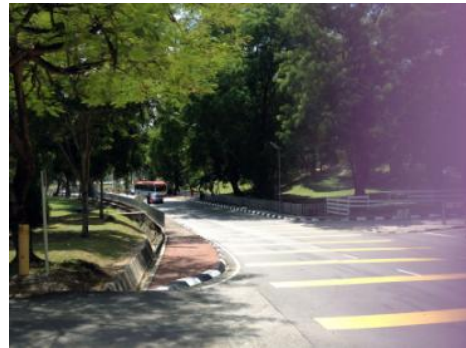

1 Primary Road

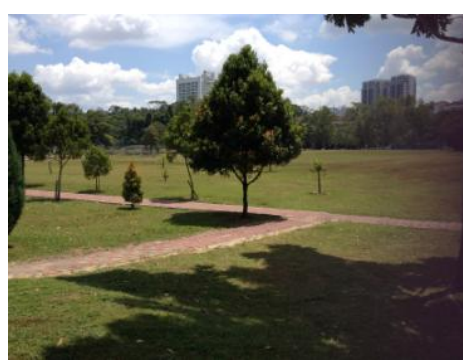

4 Open Green Space

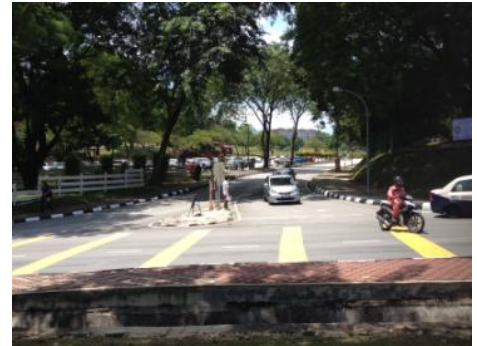

2 Secondary Road

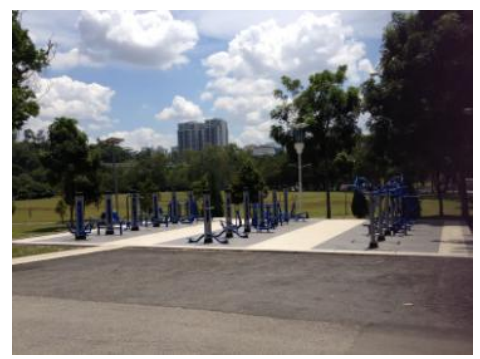

5 Parcourse

6 Journal of Design and Built Environment Vol. 17 (1), June 2017

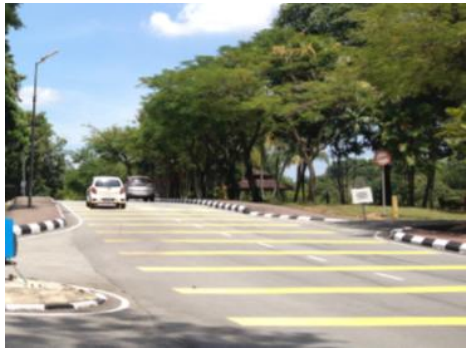

3 Primary Road

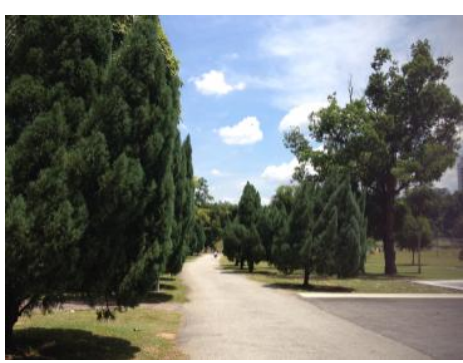

6 Tertiary Road

Engku M. et. al 


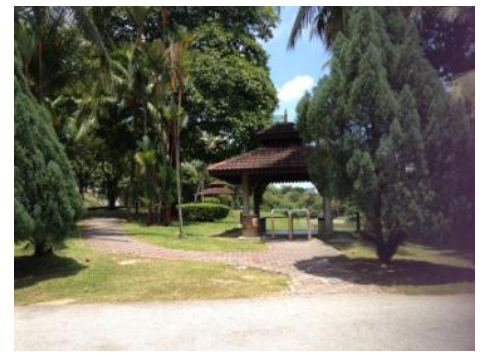

7 Gazebo

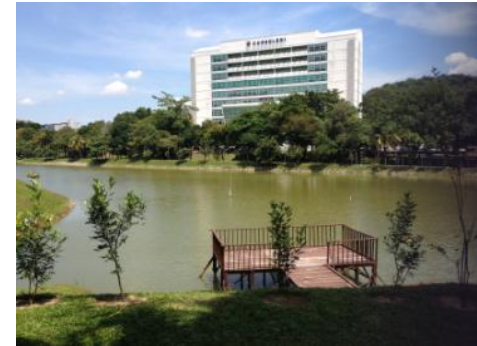

8 Lake

Figure 2: Images of Site I and its context.

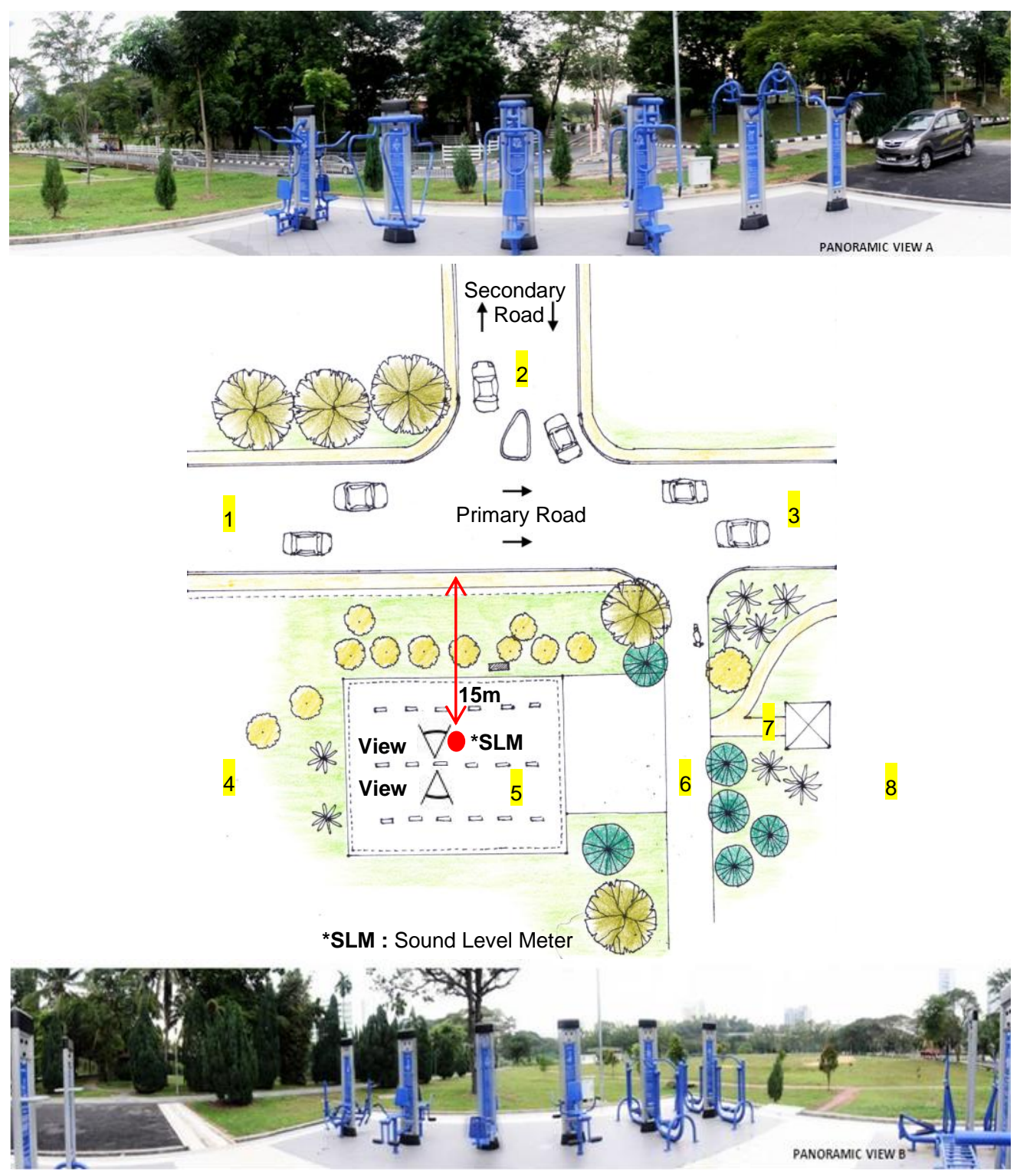

Figure 3: Layout plan and panoramic views of Site I. 
Based on Table 2, the total number of vehicles passing by during high traffic-human presence $\left(\mathrm{I}_{\mathrm{H}, \mathrm{w} \_\mathrm{H}}\right)$ is 3,511 units. The total number consist of car (2,321 units), motorcycle (1,139 units), lorry (17 units), and bus (34 units). During high traffic-no human presence $\left(\mathrm{I}_{\mathrm{H}, \mathrm{w} / \mathrm{o} \_\mathrm{H}}\right)$, the total number of vehicles is 3,650 units. The total number comprise of car (2,540 units), motorcycle (1,048 units), lorry (19 units), and bus (43 units). The large total number of vehicles can be associated with the continuous movement of traffic along the primary road.

The total of 388 units of vehicles comprises of car (317 units), motorcycle (60 units), lorry (3 units) and bus ( 8 units) were recorded during low traffic-human presence $\left(\mathrm{I}_{\mathrm{L}, \mathrm{w} \_\mathrm{H}}\right)$. During low traffic-no human presence $\left(\mathrm{I}_{\mathrm{L}, \mathrm{w} / \mathrm{o} \_\mathrm{H}}\right)$, the total number of 239 units consist of car (163 units), motorcycle (73 units), and lorry (3 units) were logged.

Table 2: Number and types of vehicles recorded at Site I.

\begin{tabular}{|c|c|c|c|c|}
\hline \multirow{2}{*}{$\begin{array}{c}\text { Type of } \\
\text { Vehicles }\end{array}$} & \multicolumn{4}{|c|}{ Site I } \\
\cline { 2 - 5 } & $\mathrm{I}_{\mathrm{H}, \mathrm{w} \_\mathrm{H}}$ & $\mathrm{I}_{\mathrm{H}, \mathrm{w} / \mathrm{o}_{-} \mathrm{H}}$ & $\mathrm{I}_{\mathrm{L}, \mathrm{w} \_\mathrm{H}}$ & $\mathrm{I}_{\mathrm{L}, \mathrm{w} / \mathrm{o} \_H}$ \\
\hline Car & 2321 & 2540 & 317 & 163 \\
\hline Motorcycle & 1139 & 1048 & 60 & 73 \\
\hline Lorry & 17 & 19 & 3 & 3 \\
\hline Bus & 34 & 43 & 8 & - \\
\hline Total & 3511 & 3650 & 388 & 239 \\
\hline
\end{tabular}

\subsubsection{SOUND MEASUREMENT}

There were four measurement periods with different circumstances conducted at Site I. The four conditions were distinguished using four different colours. For high traffic conditions, the high traffic-human presence $\left(\mathrm{I}_{\mathrm{H}, \mathrm{w}_{-} \mathrm{H}}\right)$ is represented by the red line, while high traffic-no human presence $\left(\mathrm{I}_{\mathrm{H}, \mathrm{w} / \mathrm{O} H \mathrm{H}}\right)$ is represented by the blue line. For low traffic conditions, the low traffic-human presence $\left(\mathrm{I}_{\mathrm{L}, \mathrm{w} \_\mathrm{H}}\right)$ is depicted using the green line, while the low traffic-no human presence $\left(\mathrm{I}_{\mathrm{L}, \mathrm{w} / \mathrm{o} \_\mathrm{H}}\right)$ is represented using the purple line. Referring to Figure 4, $\mathrm{I}_{\mathrm{H}, \mathrm{w} \_\mathrm{H}}$ (red line) and $\mathrm{I}_{\mathrm{H}, \mathrm{w} / \mathrm{o} \_\mathrm{H}}$ (blue line) of the graph showed high sound level of $60 \mathrm{dBA}$ and above, which was recorded during high traffic period. During low traffic period, $\mathrm{I}_{\mathrm{L}, \mathrm{w} \_\mathrm{H}}\left(\right.$ green line) and $\mathrm{I}_{\mathrm{L}, \mathrm{w} / \mathrm{o} \_\mathrm{H}}$ (purple line) of the graph basically recorded sound level of below $60 \mathrm{dBA}$. The fluctuations occurred in $\mathrm{I}_{\mathrm{L}, \mathrm{w} \_\mathrm{H}}\left(\right.$ green line) and $\mathrm{I}_{\mathrm{L}, \mathrm{w} / \mathrm{o} \_\mathrm{H}}($ purple line) of the graph was due to the vehicles passing by every once in a while during low traffic period.

According to the sound measurement data collected, between low traffic period and high traffic period, there is an increase of 5 to $10 \mathrm{dBA}$. During high traffic period, both high traffic-human presence $\left(\mathrm{I}_{\mathrm{H}, \mathrm{w}_{-} \mathrm{H}}\right)$ and high traffic-no human presence $\left(\mathrm{I}_{\mathrm{H}, \mathrm{w} / \mathrm{o} \_\mathrm{H}}\right)$ recorded $\mathrm{L}_{\mathrm{Amin}}$ of more than 50dBA and a similar $\mathrm{L}_{\mathrm{Amax}}$ of $68 \mathrm{dBA}$. During 
low traffic conditions, the $\mathrm{L}_{\mathrm{Amin}}$ recorded were below $50 \mathrm{dBA}$ and the $\mathrm{L}_{\mathrm{Amax}}$ recorded was 61 dBA for $\mathrm{I}_{\mathrm{L}, \mathrm{w}} \mathrm{H}$ and $55 \mathrm{dBA}$ for $\mathrm{I}_{\mathrm{L}, \mathrm{w} / \mathrm{o} \_\mathrm{H}}($ Table 3 ). The presence of people may have influenced the increased of $\mathrm{L}_{\mathrm{Amin}}$ during high traffic conditions and $\mathrm{L}_{\mathrm{Amax}}$ during low traffic conditions. At the time of high traffic period, the presence of human has no significant influence on the $L_{\text {Amax }}$. However, the no human presence condition could lead to the lower $\mathrm{L}_{\mathrm{Amin}}$ for both high and low traffic period.

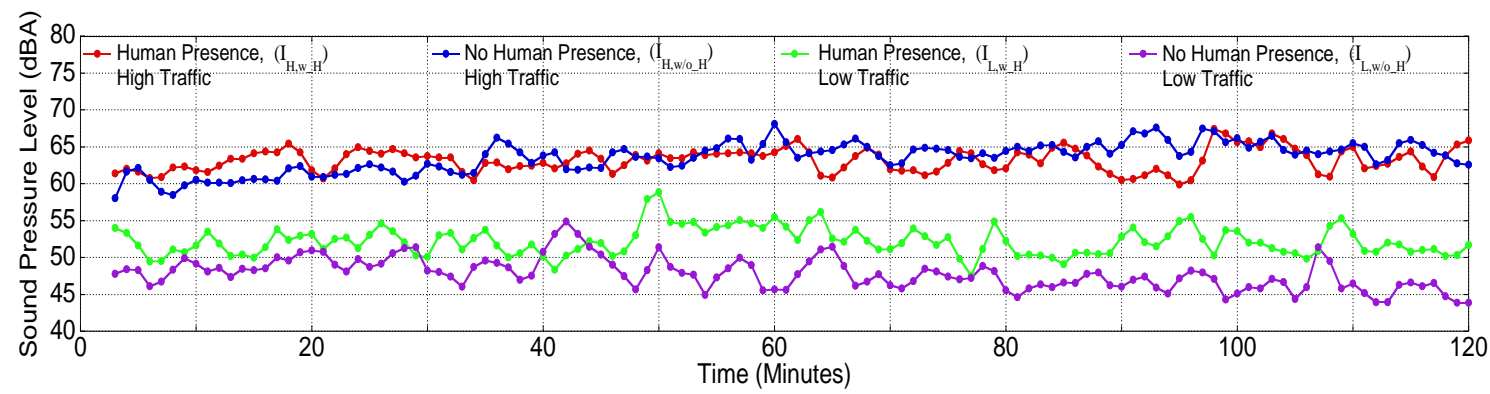

Figure 4: A-weighted sound pressure level (dBA) during high and low traffic period at Site I.

Table 3: Measured SPL parameters ( $\mathrm{L}_{\text {Amin }} \mathrm{L}_{\mathrm{Amax}}$, Mean $\left.\mathrm{L}_{\mathrm{Aeq}}\right)$ in Site $\mathrm{I}$.

\begin{tabular}{|c|c|c|c|c|}
\hline \multirow{2}{*}{$\begin{array}{c}\text { Measured SPL } \\
\text { Parameter }\end{array}$} & \multicolumn{4}{|c|}{ Site I } \\
\hline & $\mathbf{I}_{\mathbf{H}, \mathbf{w} \_\mathbf{H}}, \mathbf{d B A}$ & $\mathbf{I}_{\mathbf{H}, \mathbf{w} / \mathbf{o} \_\mathbf{H}, \mathbf{d B A}}$ & $\mathbf{I}_{\mathbf{L}, \mathbf{w} \_\mathbf{H}, \mathbf{d B A}}$ & $\mathbf{I}_{\mathrm{L}, \mathbf{w} / \mathbf{o} \_\mathbf{H}, \mathbf{d B A}}$ \\
\hline $\mathrm{L}_{\mathrm{Amin}}$ & 60 & 55 & 47 & 44 \\
\hline $\mathrm{L}_{\text {Amax }}$ & 68 & 68 & 61 & 55 \\
\hline Mean $\mathrm{L}_{\text {Aeq }}$ & 63 & 64 & 52 & 48 \\
\hline
\end{tabular}

\subsection{SITE II (WATER FEATURE AREA)}

\subsubsection{SITE OBSERVATION}

Site II is clearly visible and easily accessible as it is located next to the primary road and main buildings of UM (Rumah Universiti KKUM Berhad and Tunku Canselor Hall). Site II is an open space terrace with built-in seating provided for passive activities. The site is mainly used as a meeting point for the campus community or as a stopping point. It is a focal point area, especially during convocation seasons. The water element is located slightly further along the walkway and the primary road. The man-made waterfall-like water element generated a mild sound of waterfall
Green patch areas at the side and rear of the site are planted with various types of immature and mature vegetation including groundcover, shrubs, trees, and palms. The surrounded greenery creates a natural ambience besides providing shades for the area. Figure 5 shows the images for Site II and its context while Figure 6 presents the layout plan and panoramic images of the site. 


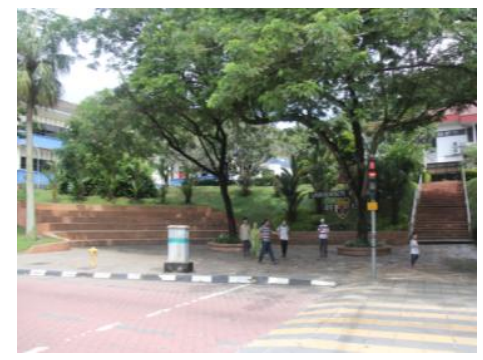

1 Terrace Area

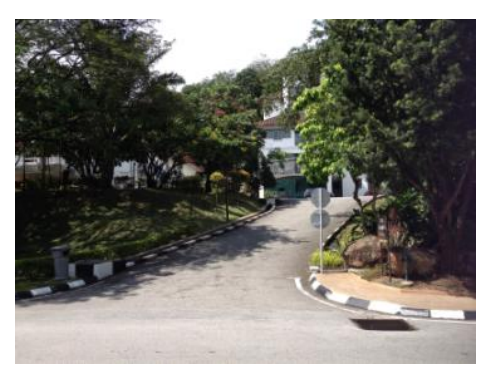

4 Secondary Road

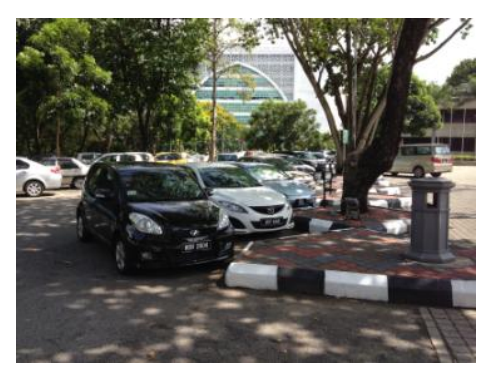

7 Parking Area

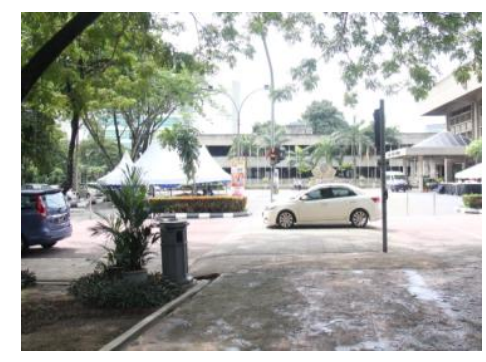

2 Pedestrian Crossing

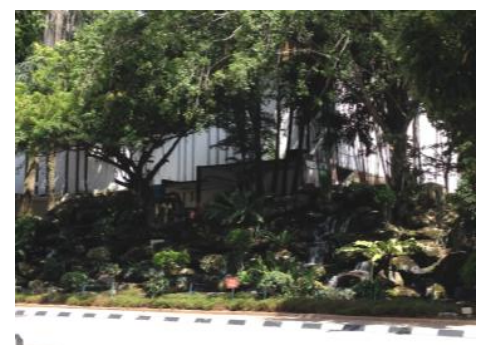

5 Water Feature

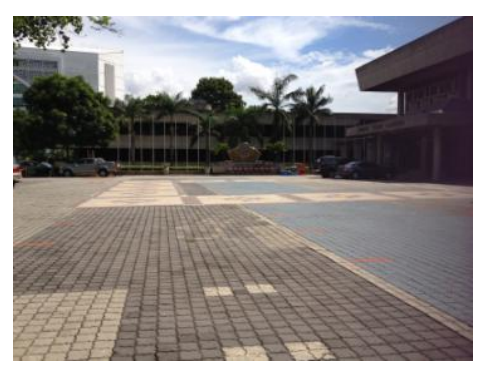

8 Open Space

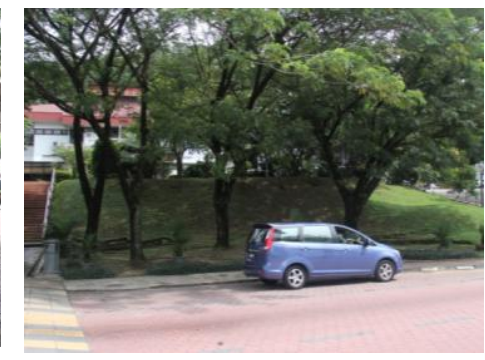

3 Green Area

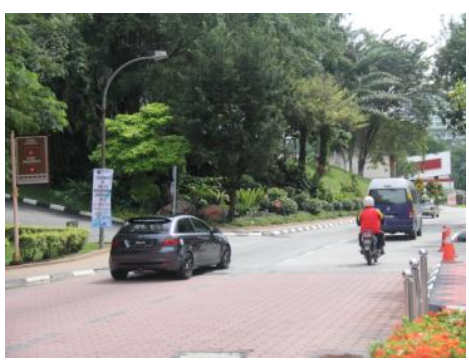

6 Primary Road

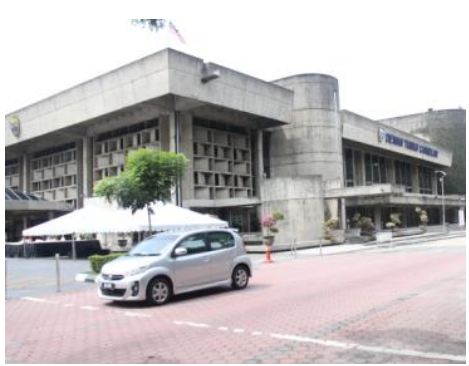

9 Tunku Canselor Hall

Figure 5: Images of Site II and its context. 


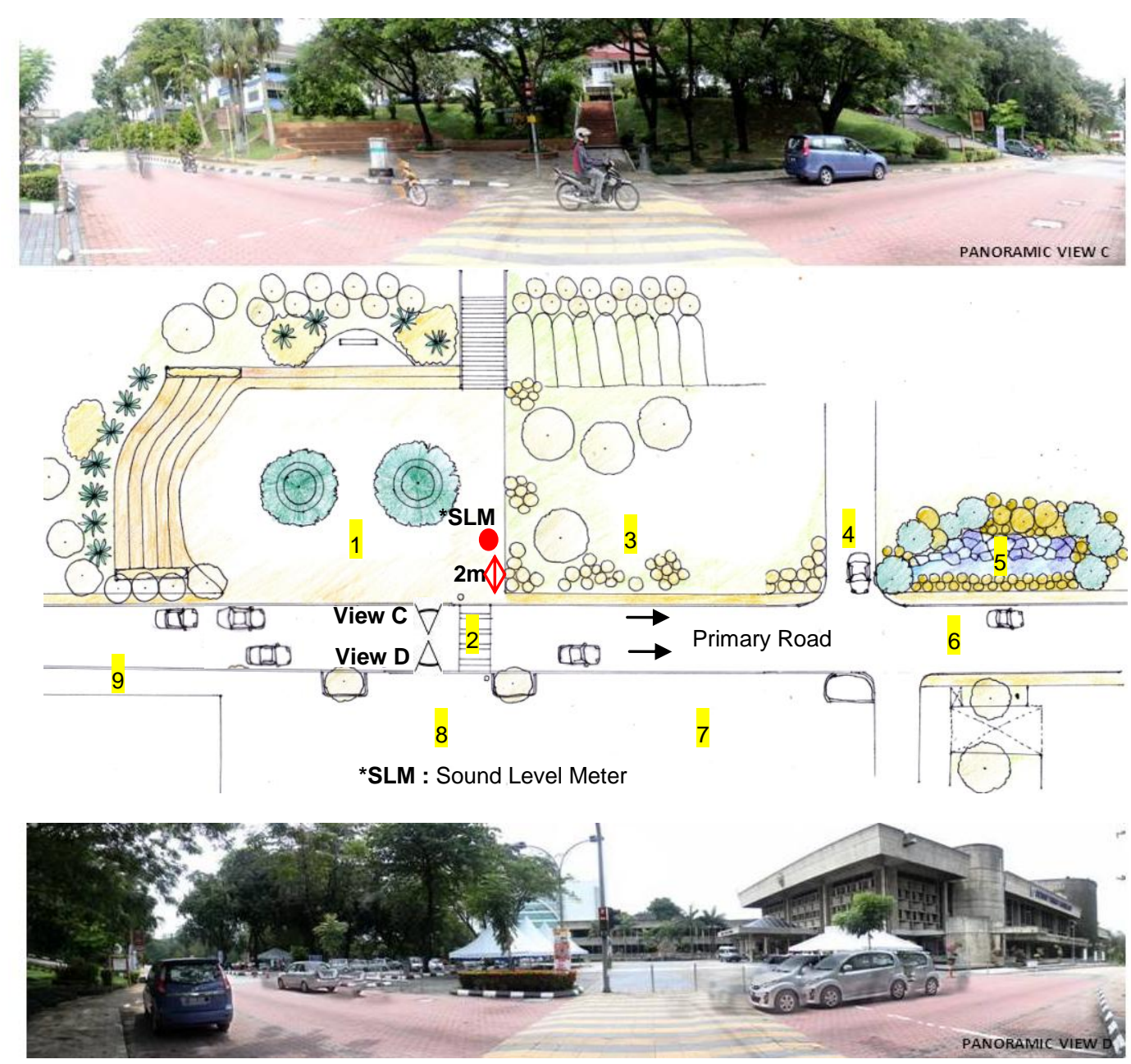

Figure 6: Layout plan and panoramic views of Site II.

Table 4 showed the total number of 2,491 units of vehicles during high traffic-water feature on $\left(\mathrm{II}_{\mathrm{H}, \mathrm{w} \_\mathrm{ON}}\right)$. The total number consists of car (1,927 units), motorcycle (518 units), lorry (13 units), and bus (33 units). The sound of the man-made waterfall can only be slightly heard as it was masked by the passing by vehicular sounds. The total number of 2,273 units of vehicles consists of car (1,693 units), motorcycle (492 units), lorry (50 units), and bus (38 units) was recorded during high traffic-water feature off
(II

The total number of vehicles recorded during low traffic-water feature on ( $\mathrm{II}_{\mathrm{L}, \mathrm{w} \_\mathrm{ON}}$ ) comprises of car (122 units), motorcycle (34 units), and lorry (3 units); makes up a total of 159 units of vehicles. The total number of vehicles logged during low traffic-water feature off ( $\left.\mathrm{II}_{\mathrm{L}, \mathrm{w} / \mathrm{o} \_\mathrm{OFF}}\right)$ is 324 units, comprises of car (269 units), motorcycle (49 units), lorry (3 units), and bus (3 units). 
Table 4: Number and types of vehicles recorded at Site II.

\begin{tabular}{|c|c|c|c|c|}
\hline \multirow{2}{*}{$\begin{array}{c}\text { Type of } \\
\text { Vehicles }\end{array}$} & \multicolumn{5}{|c|}{ Site II } \\
\cline { 2 - 5 } & $\mathrm{II}_{\mathrm{H}, \mathrm{w} \_\mathrm{ON}}$ & $\mathrm{II}_{\mathrm{H}, \mathrm{w} / \mathrm{o} \_O F F}$ & $\mathrm{II}_{\mathrm{L}, \mathrm{w} \_\mathrm{ON}}$ & $\mathrm{II}_{\mathrm{L}, \mathrm{w} / \mathrm{o} \_O F F}$ \\
\hline Car & 1927 & 1693 & 122 & 269 \\
\hline Motorcycle & 518 & 492 & 34 & 49 \\
\hline Lorry & 13 & 50 & 3 & 3 \\
\hline Bus & 33 & 38 & - & 3 \\
\hline Total & 2491 & 2273 & 159 & 324 \\
\hline
\end{tabular}

\subsubsection{SOUND MEASUREMENT}

Figure 7 shows the recorded SPL at Site II. For easier understanding of the data, the four measurement conditions were distinguished using four different colours. For high traffic conditions, the high traffic-water feature on $\left(\mathrm{II}_{\mathrm{H}, \mathrm{w} \_\mathrm{ON}}\right)$ is represented by the red line, while high trafficwater feature off $\left(\mathrm{II}_{\mathrm{H}, \mathrm{w} / \mathrm{o} \_\mathrm{OFF}}\right)$ is represented by the blue line. For low traffic measurement condition, the low traffic-water feature on $\left(\mathrm{II}_{\mathrm{L}, \mathrm{w} \_\mathrm{ON}}\right)$ is represented by the green line while the low traffic-water feature off $\left(\mathrm{II}_{\left.\mathrm{L}, \mathrm{w} / \mathrm{o} \_\mathrm{OFF}\right)}\right.$ is represented by the purple line. It can be seen that the SPL recorded during high traffic conditions are high between the ranges of 60 to $65 \mathrm{dBA}$, which suggested that the sound produced by the passing by vehicles gives prominent influence to the sound level at the site. Meanwhile, SPL recorded during low traffic conditions is around $60 \mathrm{dBA}$ and below. The gradual increase of low traffic-water feature off ( $\left.\mathrm{II}_{\mathrm{L}, \mathrm{w} / \mathrm{o} \_\mathrm{OFF}}\right) \mathrm{SPL}$ is due to more regular presence of passing vehicles during the last half time of measurement. The difference in SPL fluctuations between the high traffic and low traffic conditions should also be noted. The dissimilarities are due to intermittent flow of traffic which occurred during low traffic period measurements. The gradual increase of low traffic-water feature off $\left(\mathrm{II}_{\left.\mathrm{L}, \mathrm{w} / \mathrm{o} \_\mathrm{OFF}\right)}\right.$

During high traffic condition measurements, the $\mathrm{L}_{\mathrm{Amin}}$ of recorded sound level is more than 50 dBA. Meanwhile, the $\mathrm{L}_{\mathrm{Amax}}$ for both $\mathrm{II}_{\mathrm{H}, \mathrm{w} \_\mathrm{ON}}$ and $\mathrm{II}_{\mathrm{H}, \mathrm{w} / \mathrm{o} \_\mathrm{OFF}}$ were recorded with minimal differences in sound level of $65 \mathrm{dBA}$ and $67 \mathrm{dBA}$ respectively. For measurement during low traffic conditions, the $\mathrm{L}_{\mathrm{Amin}}$ for both $\mathrm{II}_{\mathrm{L}, \mathrm{w}_{-} \mathrm{ON}}$ and $\mathrm{II}_{\mathrm{L}, \mathrm{w} / \mathrm{o} \_\mathrm{OFF}}$ did not exceed $50 \mathrm{dBA}$. Meanwhile, the $\mathrm{L}_{\mathrm{Amax}}$ recorded for both condition logged a sound level with considerable differences with 60 $\mathrm{dBA}$ for $\mathrm{II}_{\mathrm{L}, \mathrm{w} \_\mathrm{ON}}$ and $66 \mathrm{dBA}$ for $\mathrm{II}_{\mathrm{L}, \mathrm{w} / \mathrm{o}_{-} \mathrm{OFF}}$ (refer Table 5).

The sound of the man-made waterfall influenced on the environment during low traffic conditions. Looking at the SPL data recorded, differences of an up to $10 \mathrm{dBA}$ can be observed

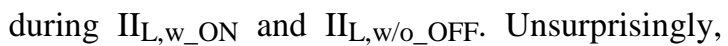
during high traffic conditions, sounds from the man-made waterfall recorded less significant masking effect as the sounds from the constant traffic flow was more outstanding. 


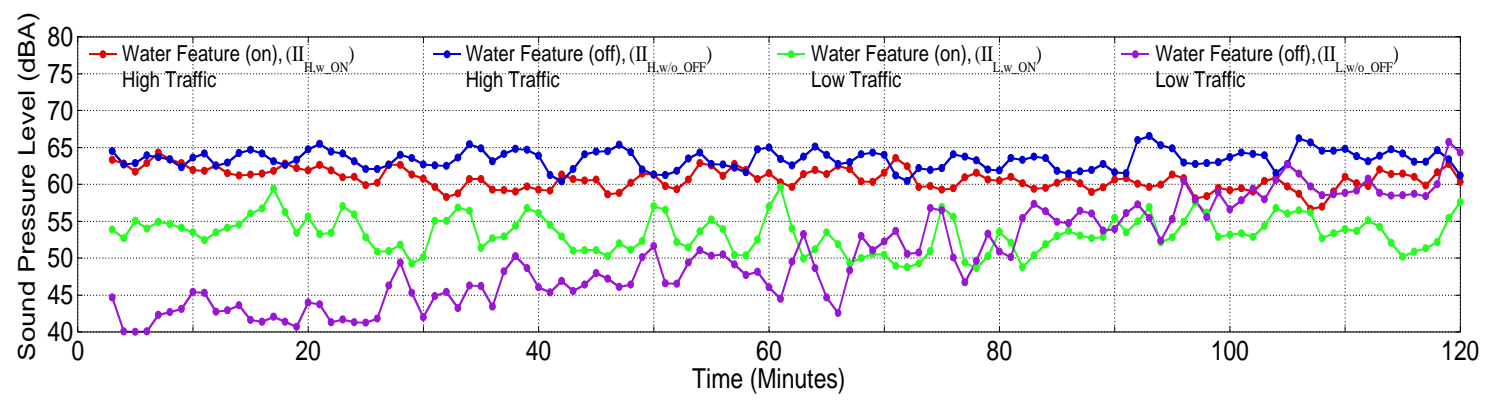

Figure 7: A-weighted sound pressure level (dBA) during high and low traffic conditions at Site II.

Table 5: Measured SPL parameters ( $\mathrm{L}_{\mathrm{Amin}}, \mathrm{L}_{\mathrm{Amax}}$, Mean $\left.\mathrm{L}_{\mathrm{Aeq}}\right)$ in Site II.

\begin{tabular}{|c|c|c|c|c|}
\hline \multirow{2}{*}{$\begin{array}{c}\text { Measured SPL } \\
\text { Parameter }\end{array}$} & \multicolumn{4}{|c|}{ Site II } \\
\hline & $\mathrm{II}_{\mathrm{H}, \mathrm{w} \_\mathrm{ON}}, \mathrm{dBA}$ & $\mathrm{II}_{\mathrm{H}, \mathrm{w} / \mathrm{o}_{2} \text { OFF }}, \mathrm{dBA}$ & II $_{L, w \_O N}$, dBA & $\mathrm{II}_{\mathrm{L}, \mathrm{w} / \mathbf{o}_{-} \text {OFFF }}, \mathrm{dBA}$ \\
\hline $\mathrm{L}_{\mathrm{Amin}}$ & 56 & 60 & 49 & 40 \\
\hline $\mathrm{L}_{\text {Amax }}$ & 65 & 67 & 60 & 66 \\
\hline Mean $\mathrm{L}_{\text {Aeq }}$ & 61 & 63 & 53 & 50 \\
\hline
\end{tabular}

\section{DISCUSSION}

This section discussed on the results of site observation and sound measurement on both sites. Site I location and the lack of plantings made it clearly visible from the primary road, hence exposing the site to vehicular sounds. The placement of the parcourse next to open green space and lake lead to the expectation of natural sounds experience. The exposure of vehicular sound towards the site created a different kind of sound environment. Unwanted or negative sound may disturb or interfere with people activities such as having conversations or dealing with mental tasks (Moudon, 2009). Vehicles are the main sound source during high traffic condition that masked the sound produced by human activities. During low traffic condition, significant differences in measured sound pressure level can be observed. The infrequent passing by of vehicle during the measurement period enable one to easily experience sounds from other sources. The possibility of clearly hearing and experiencing human sound will provide information on the presence of people and consequently, trigger vibrant atmosphere at the site.

The location of Site II next to the primary road provided a significant impact on the measured sound pressure level. Plantings surrounding the area provided a decent shade for the site. However, it failed to work as a sound barrier from the sounds of passing vehicles. The site is an open space which is clearly noticeable and easily accessible from the primary road and adjacent buildings. The distance between the water feature, the terrace, and the pedestrian crossing decreases the supposed sound effect of the waterfall. Moreover, the water feature's visual aesthetic could hardly be appreciated from 
the distance as it is situated at the far back of the area. The purpose of the water feature sound during high traffic period was lacking as it was being toned down by vehicular sounds from the primary road. Based on the observation during low traffic period, the sound of man-made waterfall was essentially audible and it provided a different environmental experience for the site.

At the events of low traffic period, the fluctuations of SPL in the graph were visibly noticeable. This is due to the fact that the low traffic conditions created a quieter environment and thus, a slight disturbance of sound produced by the passing vehicles made an obvious effect on the sound level. The sound of water at an appropriate location may evoke positive and pleasant feelings, and help in giving the environment a positive judgement (Gidlöf-Gunnarsson \& Öhrström, 2007). Yang and Kang (2005) stated that high level of pleasant sound can act as masking sound that could considerably improve the soundscape quality of an area.

Based on the discussion of Site I and Site II, the provision of landscape elements at both sites such as parcourse and water feature as well as mix setting of nature and built environment are meant for the people to enjoy and experience. The different landscape elements produce different soundscape that accentuate the character of the sites (Brown et al., 2011). But due to the location that is along the primary road exposed both sites to traffic sound. The perceived sound that is undesired due to the purpose or expectation of an area affects activities, health (Brown et al., 2011) and the soundscape quality (Kin-Che et al., 2010).

\section{CONCLUSION}

Based on the research findings, connections can be observed between the soundscape, landscape elements, site context, and traffic flow. Vehicular sounds are the only visible sound that dominated the sites when there are no human activities or water element. Daytime is the time when the environment is highly exposed to traffic noise (Din et al., 2015). During high traffic period, vehicular sounds overshadow other sounds, hence, sound generated by human activities and water feature were barely audible to human hearing. During low traffic conditions, sounds generated from sources such as human, birds, and water can be heard; but the sound from occasional passing by vehicles affected the sound pressure level is more visible. This indicates the significant impact of vehicular sounds, especially when the environment's sound level recorded below $50 \mathrm{dBA}$. The mean $\mathrm{L}_{\text {Aeq }}$ for both sites during high traffic conditions are recorded over $60 \mathrm{dBA}$, which exceeded the D.o.E (2007) permissible sound level for institutional area, which supposed to be at 50 $\mathrm{dBA}$. There is also a possibility that vehicle induced sound level was affected by the condition of the traffic flow, vehicle components (acceleration or brake), types of vehicles, and road condition.

In this case, landscape design modification can assist to enhance the quality of soundscape of the two sites. Vegetation offer functional, psychological, ecology and aesthetic advantages 
to an area and users (Adam et al., 2016). Vegetation would not only perform as visual attractions, but it is also a very economical way of providing sound buffering for the sites (Booth, 1983). The composition of trees or shrubs planted along the roadside, its arrangement; whether it is in a row or in groups; as well as the types and forms of the vegetation can influence the sound absorption and reflection. On the other hand, landscape elements such as parcourse and water feature should be strategically located. For instance, the parcourse should be placed further away from the roadside and placed within or surrounded by natural setting. Although the water feature is a visually attractive element to be located next to the roadside, for the sake of quality soundscape, it should be positioned closer to the landscape area focal point where the effect of the waterfall sound can be clearly experienced by people passing by the area.

All in all, the landscape area and the surrounding context influence the soundscape assessment. The sound that triggered and generated by the landscape elements are significantly influence by the traffic sound. The landscape and sound elements create an environment that is meant to be experienced and enjoyed by the campus community. This study focused on methods of physical observation and sound measurement only. The approach of site observation and sound measurement in assessing the environment is essential in order to understand the current situation of the site. It is hoped that psychological assessment on the users of the landscape areas can be pursued in order to look into the subjective matter regarding perception of the community towards the sound environment.

\section{ACKNOWLEDGEMENT}

A very special thanks to University of Malaya (UM) for funding this research under University of Malaya Research Grant (UMRG) project number RP009B-13SUS on "Landscape Identity of Cameron Highlands Hill Station: Cultural Landscape and Soundscape”.

\section{REFERENCES}

Adam, M., Ghafar, N. A., \& Mustapha, T. (2016), An Investigation of the Significant Criteria of Vegetation Selection and Planting Arrangement in Designing Urban Nodes, Journal of Design and Built Environment, (16)2, 1-14.

Barata, E., Cruz, L., \& Ferreira, J. P. (2011), Parking at the UC Campus: Problems and Solutions, Cities, 28(5), 406-413.

Booth, N. K. (1983), Basic elements of landscape architectural design, Waveland Press Inc, United States.

Botteldooren, D., De Coensel, B., \& De Muel, T. (2006), The Temporal Structure of Urban

Soundscape, Sound Vibration, 292(1-2), $105-123$

Brown, A. L., Kang, J., \& Gjestland, T. (2011), Towards Standardization in Soundscape Preference Assessment, Applied Acoustics, 72, 387-392.

Brown, A. L., \& Muhar, A. (2004), An approach to the acoustic design of outdoor space, Journal of Environmental Planning and Management, 47(6), 827-842. 
Cain, R., Jennings, P., \& Poxon, J. (2013), The Development and Application of the Emotional Dimensions of a Soundscape, Applied Acoustics, $74,232-239$.

Carles, J. L., Barrio, I. L., \& De Lucio, J. V. (1999), Sound influence on landscape values, Landscape and Urban Planning, 43, 191-200.

Davies, W. J., Adams, M. G., Bruce, N. S., Cain, R., Carlyle, A., Cusack, P., Hall, D. A., Hume, K. I., Irwin, A., Jennings, P., Marselle, M., Plack, C. J., \& Poxon, J. (2013), Perception of Soundscapes: An Interdisciplinary Approach, Applied Acoustics, 74, 224-231.

Department of Environment Malaysia (2007), The Planning Guidelines for Noise Limits and Control ( $2_{\text {nd }}$ ed.).

Din, N. C., Anuar, E. M. E. M., \& Hussein, H. (2015), Investigation on the Soundscape Preference and Perception of Highlands Environment: A Preliminary Study, Paper presented at the $22^{\text {nd }}$ International Congress on Sound and Vibration Conference, Florence, Italy.

Eckbo, G., Sullivan, C., Hood, W., \& Lawson, L. (1998), People in a Landscape, United States, Prentice-Hall Inc.

El-Sharkawy, M. F., \& Alsubaie, A. (2014), Study of Environmental Noise Pollution in the University of Dammam Campus, Saudi Journal of Medicine and Medical Sciences, 2(3), 178-184.

Gidlöf-Gunnarsson, A., \& Öhrström, E. (2007), Noise and well-being in urban residential environments: The potential role of perceived availability to nearby green areas, Landscape and Urban Planning, 83(2), 115-126.

Goswami, S., Nayak, S. K., Pradhan, A. C., \& Dey, S. K. (2011), A Study on Traffic Noise of Two Campuses of University, Balasore, India, Journal of Environmental Biology, 32(1), 105-109.

Jaff, P. M., \& Hossieni, H. (2012), Study of Noise Pollution at the Campus of University of Sulaimani. Journal of Kirkuk University: Scientific Studies, 7(1), 89-109.

Jennings, P., \& Cain, R. (2013), A Framework for Improving Urban Soundscape, Applied Acoustics, 74, 293-299.

Kang, J. (2007), Urban Sound Environment, Taylor \& Francis, New York.

Kang, J., \& Zhang, M. (2010), Semantic Differential Analysis of the Soundscape in Urban Open Public Spaces, Building and Environment, 45, $150-157$

Kawai, K., \& Yano, T. (2002), Relation Between the Overall Impression of the Sound Environment and Types and Loudness of Environmental Sounds, Journal of Sound and Vibration, 250(1), 41-46.

Kin-Che, L., Brown, A. L., Marafa, L., \& Kwai-Cheong, C. (2010), Human Preferences for Countryside Soundscapes, Acta Acustica united with Acustica, 96, 463-471.

Kong, S., Aziz, A. A., Rao, S., \& Inangda, N. (2009), Environmental Effects of Driving Automobiles in the University of Malaya Campus: A Pilot Study, Journal of Design and Built Environment, 5, $1-17$.

Marry, S., \& Defrance, J. (2013), Analysis of the Perception and Representation of Sonic Public Spaces Through on Site Survey, Acoustic Indicators and In-depth Interviews, Applied Acoustics, 74(2), 282-292.

Mastura E., Hussein H., \& Din C. D. (2014), Soundscape Assessment of Cameron Highlands Environment for Sustainable Development, In Towards Building Greener Cities and 
Construction at the proceedings of the $1^{\text {st }}$ International Conference on Sustainable Urban Design for Liveable Cities (SUDLiC 2014), Kuala Lumpur, Malaysia (pp. 301-312).

Meng, Q., Kang, J., \& Jin, H. (2013), Field study on the influence of spatial and environmental characteristics on the evaluation of subjective loudness and acoustic comfort in underground shopping streets, Applied Acoustics, 74(8), 1001-1009.

Moudon, A. V. (2009), Real noise from the urban environment: how ambient community noise affects health and what can be done about it, American Journal of Preventive Medicine, 37(2), $167-171$.

Musa, M. M., Ayop, S. M., Idris, M., \& Fahmi, M. (2012), Traffic Noise at UiTM Shah Alam Campus: Initial Study, 1st International Conference on Innovation and Technology for Sustainable Built Environment 2012 (ICITSBE 2012), Perak, Malaysia.

Ozcevik, A., \& Can, Z. Y. (2012), A Field Study on the Subjective Evaluation of Soundscape, Paper presented at the Acoustics 2012.

Ozer, S., Zengin, M., \& Yilmaz, H. (2014), Determination of the Noise Pollution on University (Education) Campuses: A Case Study of Ataturk University, Ekoloji, 23(90), 49-54.

Phukan, B., \& Kalita, K. (2013), An Experimental Study of Noise Pollution in Gauhati University Campus, Guwahati, Assam, India, International Journal of Environmental Sciences, 3(5), 1776-1784.

Pijanowski, B. C., Villanueva-Rivera, L. J., Dumyahn, S. L., Farina, A., Krause, B. L., Napoletano, B. M., Gage, S. H., \& Pieretti, N.
(2011), Soundscape Ecology: the Science of Sound in the Landscape, BioScience, 61(3), 203-216.

Raimbault, M., \& Dubois, D. (2005), Urban Soundscape: Experiences and Knowledge, Cities, 22, 339-350.

Schafer, R. M. (1977), The Soundscape: Our Sonic Environment and the Tuning of the World, New York, Destiny Books.

Skånberg, A., \& Öhrström, E. (2002), Adverse Health Effects in Relation to Urban Residential Soundscapes, Journal of Sound and Vibration, 250(1), 151-155.

Thompson, C. W. (2002), Urban Open Space in the 21st Century, Landscape and Urban Planning, 60(2), 59-72.

Truax, B. (1996), Soundscape, Acoustic Communication and Environmental Sound Composition, Contemporary Music Review, 15(1-2), 49-65.

Viollon, S., Lavandier, C., \& Drake, C., (2002), Influence of Visual Setting on Sound Ratings in an Urban Environment, Applied Acoustics, 63, 493-511.

Yang, W., \& Kang, J. (2005), Soundscape and Sound Preferences in Urban Squares: A Case Study in Sheffield, Urban Design, 10(1), 61-80.

Yu, C. J., \& Kang, J. (2011), Acoustic Sustainability in Urban Residential Areas, Procedia Environmental Sciences, 10, 471-477.

Zannin, P. H. T., Engel, M. S., Fiedler, P. E. K., \& Bunn, F. (2013), Characterization of Environmental Noise Based on Noise Measurements, Noise Mapping and Interviews: A Case Study at a University Campus in Brazil, Cities, 31(0), 317-327. 